\title{
Hypoalphalipoproteinemia: Prevalence and the impact of treatment on reaching HDL cholesterol target level in patients with dyslipidemia
}

\author{
Harmani Kalim
}

\begin{abstract}
Abstrak
Kadar serum "high density lipoproten cholesterol". (HDL-C) yang rendah merupakan prediktor yang kuat untuk terjadinya penyakit jantung koroner (PJK). Pada populasi laki-laki dalam penelitian Framingham diperkirakan terdapat $11 \%$ orang diantaranya yang mempunyai kadar HDL-C rendah saja dan kira-kira $30 \%$ penderita dislipidemia mempunyai kadar HDL-C < 35 mg/dl (hipoalphalipoproteinemia). Di samping itu sampai saat ini masih terdapat ketidakpastian mengenai pengelolaan penderita tersebut. Di Indonesia sekarang belum ada data epidemiologi mengenai prevalensi hipoalphalipoproteinemia dan dampak pengobatan dengan anti lipid pada kadar HDL-C pada sejumlah besar penderita. Kami telah melakukan survei di 13 kota di Indonesia untuk menilai prevalensi hipoalphalipoproteinemia diantara penderita dislipidemia dan menilai dampak pengobatan dengan anti lipid pada penderita tersebut untuk mencapai kadar target $H D L-C>35 \mathrm{mg} / \mathrm{dl}$ atau lebih pada praktek dokter rutin. Sebanyak 1420 penderita dislipidemia (rata-rata usia 50 tahun, laki-laki 58\%) telah diikut sertakan dalam survei ini. Prevalensi keseluruhan hipoalphalipoproteinemia dalam studi ini adalah $35.4 \%$ dan kekerapan tersebut berhubungan terbalik dengan tingkat risiko penderita yaitu $21.9 \%$ pada penderita risiko rendah (penderita $<2$ faktor risiko lain), $39.6 \%$ pada risiko tinggi (penderita $\geq 2$ faktor risiko lain) dan $44.3 \%$ pada penderita PJK. Setelah pengobatan 12 minggu, prevalensi tersebut menurun menjadi $12 \%, 20 \%$ dan $18 \%$ masingmasing pada kelompok risiko rendah, tinggi dan PJK. Besarnya perubahan kadar HDL-C mempunyai korelasi terbalik dengan kadar $H D L$ awal. Perubahan terbesar (59\%) terdapat pada kelompok $H D L$ rendah $(<25 \mathrm{mg} / \mathrm{dl}$ ) dan perubahan terkecil (23\%) terdapat pada kelompok HDL tertinggi ( $\geq 45 \mathrm{mg} / \mathrm{dl}$ ). Hanya terdapat $46 \%$ dengan $H D L-C<35 \mathrm{mg} / \mathrm{dl}$ pada saat awal yang dapat mencapai kadar $H D L-C$ sesuai target NCEP (> $35 \mathrm{mg} / \mathrm{dl}$ ) setelah terapi 12 minggu. (Med J Indones 2001; 10: 98-102)
\end{abstract}

\begin{abstract}
A low serum high density lipoprotein cholesterol $(H D L-C)$ level is a potent predictor of coronary heart disease (CHD). It has been estimated that $11 \%$ of the Framingham men have isolated low $H D L-C$ levels and about $30 \%$ of dyslipidemia patients have HDL-C level of less than $35 \mathrm{mg} / \mathrm{dl}$ (hypoalphalipoproteinemia). In addition, there is uncertainty regarding the management of these patients. There is no epidemiological data on the prevalence low $H D L-C$ level in dyslipidemia patients and the results of treatment on $H D L-C$ on a large number of patients in Indonesia. We conducted a survey in 13 cities in Indonesia to evaluate the prevalence of hypoalphalipoproteinemia among dyslipidemic patients and the impact of treatment with lipid modification drugs on achieving target level of HDL-C $35 \mathrm{mg} / \mathrm{dl}$ or more in routine clinical practice. A total number of 1420 dyslipidemia patients (mean age 50 years, male $58 \%$ ) were included and analyzed in this report. The overall prevalence of hypoalphalipoproteinemia in our study was $35.4 \%$ and it was correlated with the risk level of the patients; $21.9 \%$ among low risk group (patients with $<2$ other risk factor), 39.6\% in high risk group ( $\geq 2$ other risk factors) and $44.3 \%$ in patients with CHD. After 12 weeks treatment, the prevalence decreased to $12 \%, 20 \%$ and $18 \%$ in low risk, high risk and CHD patients respectively. The magnitude of $H D L-C$ changes correlated inversely with base-line $H D L-$ $C$ and it was highest $(59 \%)$ in the lowest $H D L-C$ group $(<25 \mathrm{mg} / \mathrm{dl})$ and the least change $(23 \%)$ was found in group with the highest $H D L-C$ level $(>45 \mathrm{mg} / \mathrm{dl}$ ). Only $46 \%$ of patients with low $H D L-C$ value at baseline achieved normal $H D L-C$ level after treatment. In conclusion, the prevalence of low HDL-C in dyslipidemia patients was high especially in high risk group and in CHD patients. The majority of patients with low HDL-C at base-line could not reach the target level for HDL-C of $35 \mathrm{mg} / \mathrm{dl}$ or more after 12 weeks treatment with lipid modification drugs. (Med J Indones 2001; 10: 98-102)
\end{abstract}

Keywords: hypoalphalipoproteinemia, dyslipidemia, routine practice, anti lipid drugs

Many studies in the past three decades have established the correlation of dyslipidemia with the

Department of Cardiology, Faculty of Medicine University of Indonesia, Harapan Kita Hospital/ National Cardiac Center. Jakarta, Indonesia risk of coronary heart disease (CHD). The triad of high triglycerides, low high-density lipoprotein cholesterol (HDL-C), and elevated low-density lipoprotein cholesterol (LDL-C) were the most important factors in predicting risk of CHD. It has also been long known that HDL-C concentration is 
inversely associated with atherosclerosis risk. ${ }^{1}$ Low level of HDL-C (hypoalphaproteinemia) could predict an increased incidence of $\mathrm{CHD}$, independent of other risk factors. ${ }^{2,3}$

Although LDL cholesterol has been the main target in lipid-lowering therapy, ${ }^{4}$ in fact, a high LDL cholesterol was not the most prevalent lipoprotein phenotype in many population with high $\mathrm{CHD}$ rates. Low HDL cholesterol alone or reduced HDL combined with increased remnant lipoproteins are the more common phenotypes. ${ }^{5}$ Data from the Munster Heart Study (PROCAM) showed that, after follow-up at 8 years. HDL-C level below $35 \mathrm{mg} / \mathrm{dl}$ was associated with a fivefold increase in risk of $\mathrm{CHD}$ compared to normal HDL-C values even if total cholesterol lay between 200 and $300 \mathrm{mg} / \mathrm{d} 1{ }^{6}$

Two primary prevention trials (the Lipid Research Clinics Primary Prevention Trial and the Helsinki Heart Study) both demonstrated that increasing HDL cholesterol levels reduced CHD events independent of the effect on LDL lowering. Furthermore the recent Veterans Affairs High Density Lipoprotein Cholesterol Intervention Trial (VA-HIT) showed that treatment with the fibrate gemfibrozil resulted in a significant $22 \%$ reduction in fatal CHD and non-fatal myocardial infarction in patients with CHD whose primary lipid abnormality was a low HDL cholesterol level (mean baseline levels were $32 \mathrm{mg} / \mathrm{dl}$ ). In VA-HIT gemfibrozil-treatment patients achieving an ontreatment HDL cholesterol level above $35 \mathrm{mg} / \mathrm{dl}$ had the lowest CHD event rate and this was seen even in the presence of high triglyceride levels. The American Heart Association (AHA) guidelines on the primary and secondary prevention of $\mathrm{CHD}$ recommended that the secondary goal for lipid management is to increase HDL-C level to $>35 \mathrm{mg} / \mathrm{dl}$.

In Indonesia there is no study that evaluated the prevalence of low HDL-cholesterol and the impact of lipid modification treatment on reaching target goal of HDL-cholesterol level in routine clinical practice. In view of the VA-HIT and Framingham data, we wanted to evaluate to what extend treatment was able to raise levels of HDL cholesterol to above $35 \mathrm{mg} / \mathrm{dl}$.

The aim of this study is to evaluate the prevalence of low HDL-C in patients with dyslipidemia and the results of anti lipid treatment on $\mathrm{HDL}$ cholesterol in routine clinical practice.

\section{METHODS}

\section{Study Design and Population}

This was a retrospective study in 13 cities in Indonesia which invited the participation of physicians who regularly treated patients with dyslipidemia. These physicians were asked to enroll about 10 consecutive dyslipidemia patients who received lipid modification therapy. Adult patients with primary dyslipidemia who received the same anti-lipid therapy for at least 12 weeks were eligible in the study if they did not have major trauma, surgery that required anesthesia, or myocardial infarction within the past 12 weeks prior to the study. Those who had an acute infection that required current antibiotic therapy or a recent or abrupt change in their usual diet or exercise within the preceding month were excluded. Women who were pregnant, breastfeeding, or $<6$ months post partum were also excluded.

\section{Case Record Form (CRF)}

Physicians who participated in this study were required to fill standardized CRF for each patient. The CRF contained patient's ID, age, sex, CHD risk factors, prevalence of CHD, metabolic liver or kidney disease, baseline and after treatment lipid profile and lipid modification drugs used.

\section{Risk Factor Assessment and Risk Groups}

Risk factors were determined for each patients, and based on the sum of the risk factor (s) he/she had, the patient was categorized in one of the three risk. categories : low-risk group, high-risk group and CHD patients. Patients without $\mathrm{CHD}$ and have fewer than 2 risk factors other than dyslipidemia are categorized as low-risk group, while patients without $\mathrm{CHD}$ with 2 or more risk factors other than dyslipidemia are categorized as high-risk group. CHD patients are those who have clinical manifestations of coronary heart disease, i.e.: angina pectoris, history of myocardial infarction and surgical or non surgical or non surgical intervention for CHD.

Risk factors assessment were done following the NCEP definition of risk factors. Age risk factor was defined as $>45$ years for male and $>55$ years for female. Family history was considered positive if the patients father or brother died suddenly or of CHD 
below 55 years of age, and for mother or sister died suddenly or of CHD below 65 years of age. Smoking was defined as current smoking, while hypertension was indicated as blood pressure $>140 / 90 \mathrm{mmHg}$ or on anti hypertensive medication. Low HDL-C level was $<35 \mathrm{mg} / \mathrm{dl}$ and diabetes mellitus was defined as history of diabetes mellitus or under anti diabetes medication or random blood glucose $>200 \mathrm{mg} / \mathrm{dl}$.

\section{Determination of Lipid Profile}

Measurement of total cholesterol, triglycerides and HDL-C were made at baseline and at least 12 weeks after treatment. LDL-C values were calculated using Friedewald formula. Measurement of baseline lipid profile were carried out with enzymatic immunoassay method (Chod-pap) using automatic photometer equipment (Hitachi).

\section{Data Analysis}

Because of the uncontrolled nature of treatment in this study that precludes the use confirmation statistics, all data were analyzed and are presented using descriptive methods.

\section{RESULTS}

\section{Baseline Patient Characteristics}

There were 1633 patients enrolled in this study, but because of incomplete data 283 patients were excluded. In total 1420 patients had completed CRF and all of them were included in this report. Table 1 shows the baseline characteristics of the study participants. At baseline $25.7 \%$ of the patients belong to low risk group, $66.0 \%$ to high risk group and $18.3 \%$ patients with CHD. As expected, patients with $\mathrm{CHD}$ and patients with more than 2 risk factors (high risk group) were more likely than the low risk group to be older and to have low HDL-C levels.

\section{CHD Risk Profile in Relation to Baseline HDL-C levels}

Five hundred and three out of the total study participants (35.4\%) had HDL-C level of less than 35 $\mathrm{mg} / \mathrm{dl}$. Patients with low HDL-C level had less risk factors than patients with HDL-C level of equal or more than $35 \mathrm{mg} / \mathrm{dl}$ (Table 2).

\section{HDL-C changes After Treatment by Risk Group}

Table 3 shows HDL-C level changes after treatment by risk group. It is apparent that the increase of HDL-

Table 1. Patients demographics and base line lipid profile

\begin{tabular}{lcccc}
\hline & $\begin{array}{c}\text { Low risk } \\
(\mathrm{n}=366)\end{array}$ & $\begin{array}{c}\text { High risk } \\
(\mathrm{n}=939)\end{array}$ & $\begin{array}{c}\text { CHD patients } \\
(\mathrm{n}=115)\end{array}$ & $\begin{array}{c}\text { Total } \\
(\mathrm{n}=1420)\end{array}$ \\
\hline Mean Age (SD) yrs & $43.1(9.6)$ & $52.4(10.1)$ & $54.3(11.5)$ & $50.3(0.9)$ \\
Male (\%) & 51.3 & 61.0 & 59.6 & 58.4 \\
Female (\%) & 48.7 & 39.0 & 40.4 & 41.6 \\
BMI (kg.m2) & $23.3(2.8)$ & $25.2(3.0)$ & $25.1(2.6)$ & $24.8(3.1)$ \\
Lipid Profile (mg/dL) & 271 & 267 & 270 & 268 \\
Total cholesterol & $(54)$ & $(47)$ & $(58)$ & $(50)$ \\
LDL-C & $192(47)$ & $187(46)$ & $398(58)$ & $189(47)$ \\
HDL-C & $44.3(13.8)$ & $39.9(11.5)$ & $39.0(10.7)$ & $41.1(12.2)$ \\
Low HDL-C $(\%)$ & 21.9 & 39.6 & 44.3 & 35.4 \\
Triglyceride & $207(98)$ & $232(105)$ & $237(99)$ & $226(104)$ \\
\hline
\end{tabular}

Table 2. Prevalence of risk factors in patients with high and low HDL-C at baseline

\begin{tabular}{lcc}
\hline Risk factor & $\begin{array}{c}\text { HDL- } \mathrm{C}<35 \mathrm{mg} / \mathrm{dl} \\
(\mathrm{N}=503)\end{array}$ & $\begin{array}{c}\text { HDL-C }>35 \mathrm{mg} / \mathrm{dl} \\
(\mathrm{N}=917)\end{array}$ \\
\hline Age & 139 & 576 \\
Smoking & 89 & 318 \\
Hypertension & 89 & 420 \\
Family history & 48 & 149 \\
Diabetes mellitus & 32 & 154 \\
Obesity & 6 & 43 \\
\hline
\end{tabular}


$\mathrm{C}$ level was greater in high risk group. CHD patients showed the greatest changes in HDL-C level, followed by high risk group and least change in HDL$\mathrm{C}$ values was found in the low risk group.

\section{Percentage of Patient Achieving Normal HDL-C level (HDL-C > 35 mg/dl) After Treatment}

The effect of treatment on HDL cholesterol stratified according to baseline levels in shown in Table 4. Significant increases in HDL-C were seen in all cumulative baseline group, the effect being iversely related to the baseline level of HDL cholesterol.

Hence the largest proportional increase in HDL cholesterol $(59 \%)$ was seen in the group with the lowest mean baseline levels $(<25 \mathrm{mg} / \mathrm{dl})$ and the least increase $(2.6 \%)$ was seen in group with HDL cholesterol levels $\geq 45 \mathrm{mg} / \mathrm{dl}$. After 12 weeks treatment with lipid modification drugs, only $46 \%$ of patients with baseline HDL-C levels of less than 35 $\mathrm{mg} / \mathrm{dl}$ achieved HDL-C target of $35 \mathrm{mg} / \mathrm{dl}$ or more. The properties of patients who did not reach target level of HDL-C in those, with HDL-C at baseline of < $25 \mathrm{mg} / \mathrm{dl}$, between $25-29 \mathrm{mg} / \mathrm{dl}$ and between 30-34 $\mathrm{mg} / \mathrm{dl}$ were $70 \%, 72 \%$ and $44 \%$ respectively.

\section{DISCUSSION}

Low levels of HDL cholesterol are associated with an increase risk of coronary artery disease events, and high levels of HDL cholesterol are associated with protection from coronary artery diseases.

Recent findings indicate that low HDL-C (with normal LDL-C) occurs in up to $30 \%$ of patients with $\mathrm{CHD}$ and may represent a larger proportion of the CHD population than do those with isolated high LDL-C. ${ }^{4}$ A biologically plausible mechanism has been proposed to explain how HDL-C exerts its antiatherogenic effect.

There are several classess of anti lipid drugs available for physicians including bile acid binding resins, niacin,3-hydroxy-3 methyl glutaryl coenzyme A (HMG-CoA) reducatase inhibitors (statins), fibric acid, probucol and estrogens.

The 1993 National Cholesterol Education Program Adult Treatment Panel II guidelines place primary emphasis on LDL cholesterol levels, however it stated that HDL-C level $<35 \mathrm{mg} / \mathrm{dl}$ is an independent risk factor for $\mathrm{CHD}$ and the need for HDL cholesterol screening in all adults. In this guidelines, no statement was made as regard to the importance of raising low level of $\mathrm{HDL}$ cholesterol in both primary and secondary prevention of CHD. The American College of Physicians and the Joint Task Force of European and other Societies on Coronary Prevention do not also formally stated low HDL cholesterol as a specific target of therapy.

Tabel 3. Percentages changes of HDL-C after treatment by risk group

\begin{tabular}{|c|c|c|c|c|c|c|}
\hline \multirow[t]{2}{*}{ Risk group } & \multicolumn{3}{|c|}{ HDL-C mean (SD) (mg/dL) } & \multirow[t]{2}{*}{$\%$ Change } & \multicolumn{2}{|c|}{$\%$ Patients with low HDL-C } \\
\hline & $\mathrm{N}$ & Before & After & & Before & After \\
\hline $\begin{array}{l}\text { Low risk } \\
\text { High risk } \\
\text { CHD }\end{array}$ & $\begin{array}{l}366 \\
939 \\
115 \\
\end{array}$ & $\begin{array}{c}44.3(13.8) \\
39.92(11.52) \\
39.04(10.72)\end{array}$ & $\begin{array}{c}48.7(13.09) \\
44.50(11.96) \\
44.86(10.86)\end{array}$ & $\begin{array}{l}+12.15(23.45) \\
+14.56(27.77) \\
+21.05(53.10) \\
\end{array}$ & $\begin{array}{l}21.9 \\
39.6 \\
44.3 \\
\end{array}$ & $\begin{array}{l}12.06 \\
20.34 \\
18.26 \\
\end{array}$ \\
\hline Total & 1420 & $41.06(12.18)$ & $45.62(12.31)$ & $+14.47(29.71)$ & 35.4 & 18.04 \\
\hline
\end{tabular}

Tabel 4. Percentages of patients achieving HDL-C $>35 \mathrm{mg} / \mathrm{dl}$ after treatment by baseline HDL-C

\begin{tabular}{|c|c|c|c|c|c|}
\hline \multirow{2}{*}{$\begin{array}{c}\text { Baseline } \\
\text { Level HDL-C } \\
(\mathrm{Mg} / \mathrm{dl})\end{array}$} & \multicolumn{3}{|c|}{ HDL-C mean (SD) (mg/dL) } & \multirow{2}{*}{$\begin{array}{l}\text { Mean HDL-C } \\
\text { changes }(\%)\end{array}$} & \multirow{2}{*}{$\begin{array}{c}\% \text { Patients with } \\
\text { HDL-C }>35 \mathrm{mg} / \mathrm{dl} \\
\text { after treatment }\end{array}$} \\
\hline & $\mathrm{N}$ & Before & After & & \\
\hline $\begin{array}{l}<25 \\
25-29 \\
30-34 \\
35-39 \\
40-44 \\
\geq 45\end{array}$ & $\begin{array}{c}43 \\
91 \\
245 \\
334 \\
246 \\
459 \\
\end{array}$ & $\begin{array}{l}20.71 \\
26.80 \\
31.54 \\
36.57 \\
41.08 \\
54.17\end{array}$ & $\begin{array}{l}32.90 \\
33.26 \\
38.13 \\
41.81 \\
46.54 \\
55.56\end{array}$ & $\begin{array}{r}58.86 \\
24.10 \\
20.89 \\
14.33 \\
13.29 \\
2.56\end{array}$ & $\begin{array}{l}30.32 \\
27.47 \\
55.92 \\
91.02 \\
97.15 \\
96.73\end{array}$ \\
\hline
\end{tabular}


All of the patients included in our study were patients treated with anti lipid drugs in routine clinical practice in 13 cities in Indonesia. They were $58 \%$ men and $42 \%$ women, mean age 50 years. Most of them (72\%) belong to high risk group (patients with 2 or more CHD risk factors other than dyslipidemia) and $\mathrm{CHD}$ patients.

The prevalence of low HDL cholesterol level in our study $(<35 \mathrm{mg} / \mathrm{dl}$ ) varied from $16 \%$ in low risk group to $30 \%$ in high risk group and $33 \%$ in patients with CHD (overall prevalence $35 \%$ ). This figure is lower than the prevalence of low HDL cholesterol level in CHD patients reported in Framingham Study, i.e. $57 \%$. However, similar study is Germany found that 2078 out of 7097 dyslipidemia patients (about 29\%) treated in clinics had HDL cholesterol level of $<35$ $\mathrm{mg} / \mathrm{dl}$. The mean increase in HDL cholesterol levels from baseline for the total population was $15 \%$ and the most pronounced effect $(59 \%$ increase from baseline) was observed in those patients who were in the lowest baseline HDL cholesterol group. Although these are not placebo-corrected data the changes in lipid fraction which occurred in those randomized to placebo in the large clinical trials were trivial and hence, placebo correction is unlikely to significantly effects the size of these reported changes in HDL cholesterol.

The results of the present study showed that there were still many patients with low HDL-C level at baseline who did not reach target HDL cholesterol level of $35 \mathrm{mg} / \mathrm{dl}$ or more after treatment. About $18 \%$ of patients with CHD $20 \%$ of high risk group and $12 \%$ of low risk group (overall patients $18 \%$ ) had low HDL cholesterol leve after treatment. This is in contrast to the results of several large drug monitoring programmes in Europe in which fibrate was used for the treatment of dyslipidemia patients. These studies showed that all patients had HDL cholesterol levels of more than $35 \mathrm{mg} / \mathrm{dl}$ after treatment regardless the baseline HDL-C levels. ${ }^{10,11}$ In our survey, $76 \%$ of the dyslipidemia patients were treated with statin and $21 \%$ with fibrate. It is known that fibrate can increase HDL cholesterol better than statin. The effects of fibrate on HDL cholesterol are mediated, at least in parts, through changes in transcription of genes encoding for proteins that control lipoprotein metabolism. ${ }^{9}$

In conclusion, this study has shown that within everyday clinical setting among dyslipidemic patients in Indonesia, the prevalence of patients with low HDL cholesterol levels is comparable to the Western countries. Many patients still had HDL cholesterol level of less than $35 \mathrm{mg} / \mathrm{dl}$ despite anti-lipid treatment.

\section{Acknowledgements}

The authors wish to thank all the doctors in 13 cities who participated in this study, and to PERKI who endorsed this study.

\section{REFERENCES}

1. Rader DJ. Pathophysiology and management of low highdensity lipoprotein cholesterol. Am J Cardiol 1999; 83:224.

2. Boden WE, Pearson TA. Raising low levels of highdensity lipoprotein cholesterol is an important target of therapy. Am J Cardiol 2000; 85:645-50.

3. Poulter Neil. The impact of micronized fenofibrate on lipid subfraction and on reaching HDL-target levels in 7098 patients with dyslipidemia. Br J Cardiol 1999; 6:682-5.

4. Harper CR, Jacobson TA. Treating isolated low highdensity lipoprotein cholesterol; prescient or premature? Am J Cardiol 2000; 85:484-6.

5. Rubins HB, Robins SJ, Collins Dorothea, Fye CL, Anderson JW, Elam MB, et al. Gemfibrozil for the secondary prevention of coronary heart disease in men with low levels of high-density lipoprotein cholesterol. New England J Med 1999; 341:410-8.

6. Harper CR, Jacobson TA. New perspective on the management of low levels of high-density lipoprotein cholesterol, Arch Intern Med 1999; 159:1049-57.

7. Kwiterovich Peter $\mathrm{O}$. The antiatherogenic role of highdensity lipoprotein cholesterol. Am J Cardiol 1998; 82:1321.

8. Saku Keijiro. Hyperinsulinemic hypoalphalipoproteinemia as a new indicator for coronary heart disease. J Am Coll Cardiol 1999; 34:1443-51.

9. Staels B, Dallongeville J, Awers J, Schoonjans K, Aeiterdorf E, Fruchard JC. Mechanism of Action of fibrates on lipid and lipoprotein metabolism. Circ 1998; 98:2088-93.

10. Poulter Neil. The impact of micronized fenofibrate on lipid subfractions and on reaching HDL-target levels in 7098 patients with dyslipidemia. Br J Cardiol 1999; 6:682-5.

11. Kuchguszler KU, Schmitz H, Bach G. Effectiveness and Tolerability of 12 weeks treatment with micronized fenofibrate $200 \mathrm{mg}$ in a drug monitoring programme involving 9884 patients with dyslipidemia. Clin Drug Invest 1998; 15:197-204. 